\title{
Nailfold capillaroscopy in systemic diseases: short overview for internal medicine
}

\author{
ALINA DIMA, IOANA BERZA, DANIELA NICOLETA POPESCU, MAGDA ILEANA PARVU
}

Department of Rheumatology, Colentina Clinical Hospital, Bucharest, Romania

\begin{abstract}
Nailfold capillaroscopy (NFC) is now one of the main imaging tools in systemic sclerosis and imposed over time as an easy, non-invasive method for the nailfold microvascular bed assessment.

In qualitative NFC normal pattern is characterized by homogeneous, parallel fashion arrangement of the last capillaries row as well as by capillaries with hairpin or non-specific variations like tortuous and/ or crossing shape.

Nailfold capillaroscopy is strongly recommended for evaluation of all patients with Raynaud phenomenon. Appearance of giant capillaries is chronologically the first relevant finding for scleroderma spectrum disorders development (systemic sclerosis, dermatomyositis, undifferentiated and mixed connective tissue disease). Collapses of the giant loops generate microhemorrhages and further capillary loss with subsequent hypoxia, and neoangiogenesis seen as ramified/ bushy capillaries. Nailfold capillaroscopy is indicated especially in systemic sclerosis, being also included in the classification criteria.

Based on these major NFC pathologic findings (giant capillaries, microhemorrhages, avascularity and neoangiogenesis), three evolutive stages were described in systemic sclerosis, namely the early, active, and late scleroderma pattern.

In other connective tissue diseases than those scleroderma-related, like systemic lupus erythematosus, psoriatic arthritis, or antiphospholipid syndrome, the interest for capillaroscopy is growing, but the attempts of defining specific characteristics failed until now.

Besides qualitative NFC, semiquantitative and quantitative capillaroscopic assessments were proposed for more accurate evaluation. Lately, automated systems are under development. There is still need of more studies to sustain the nailfold capillaroscopy validity as diagnostic and prognostic test.
\end{abstract}

Key words: nailfold capillaroscopy, systemic sclerosis, microangiopathy, video capillaroscopy.

\section{BACKGROUND}

Nailfold capillaroscopy (NFC) is a non-invasive, easy to use, low cost, reproductible technique, that allows visualization of the capillary network in living tissues [1-3] and plays an important role in rheumatology clinical practice [4].

It appears that the first clinician who used a microscope to visualize the small blood vessels visible around the nails was Johan Christophorous Kolhaus in 1663 [2]. Later on, at the beginning of 1800 , Giovanni Rasori used a magnifying glass to describe the capillary loops characteristics [2,5] and Maurice Raynaud presented his thesis on the local hand and feet ischemic damage in 1862 [5]. Further, efforts were done to define the stages of dilatated capillaries and nailfold petechiae occurrence in different connective-tissue disorders [6]. There were many attempts to describe disease specific capillaroscopic findings, like increased visibility in rheumatoid arthritis (RA), marked capillary dilatation in systemic sclerosis ( $\mathrm{SSc}$ ) and dermatomyositis (DM), or distinction of the subpapillary vessels with „punched-out" lesions in systemic lupus erythematosus (SLE) [7]. Maricq HR et al. defined the scleroderma pattern, characterized by giant capillaries and/or rarefaction and disorganization of capillaries with multiple branches formation, as well as changes of the blood flow in patients with Raynaud phenomenon (RP) [8-9].

In 2000, Cutolo $\mathrm{M}$ et al. defined three main patterns in systemic sclerosis ( $\mathrm{SSc}$ ) that are currently largely used, namely the E (early), A (active), and L (late) pattern [10]. Besides the qualitative capillaroscopy description that allows definitions of normal as well as of pathologic patterns, semi-/quantitative capillaroscopic evaluations were also developed [11,12]. 
The 2013 American College of Rheumatology (ACR)/ EULAR classification criteria for SSc counts 2 out of the minimum 9 points needed for the pathology classification for NFC SSc-specific findings [13]. The inclusion of the capillaroscopic evaluation in the SSc classification criteria was based on its role in early SSc diagnosis; later the capillaroscopy indications expanded (see Table 1) [8]. The 2013 ACR /EULAR proved better sensitivity and specificity when compared to 1980 ACR classification criteria, respectively 0.91 and 0.92 versus 0.75 and 0.72 [13]. There is need for more data to conclude over the NFC accuracy as a diagnosis or prognostic tool in SSc and in other rheumatic diseases [14].

Recently, standardization guidelines for capillaroscopy practice for RP and SSc were published by the EULAR study group on microcirculation in rheumatic diseases and the scleroderma clinical trials consortium group on capillaroscopy [15].

We herein present a short overview of the NFC main features and use in daily clinical practice as well as the advances done for the NFC use in other rheumatic diseases than SSc.

\section{IMAGING TECHNIQUE}

NFC allows the non-invasive "in vivo" examination of the peripheral microcirculation [5]. The term microcirculation refers to micro-vessels with less than $300 \mu \mathrm{m}$ diameter [11]. Instruments of optical magnification developed for the examination of nailfold dermal papillary capillaries [16] are the stereomicroscope, ophthalmoscope, dermatoscope, smartphone devices, digital USB microscope, and digital videocapillaroscope [15].

The videocapillaroscope is most recommended based on the strengths of better images quality and improved software for image processing and measurements. The nailfold videocapillaroscope has a digital optical probe with a fixed magnification power. Some devices have low magnification power (x20), while other allow high amplification, most frequently x200 $[5,8,16]$. A power of magnification higher than $\times 60$ is necessary for a good capillaroscopic image, and magnification higher than x1000 allows to observe well even the erythrocyte passage through the capillaries loops [17]. A videocapillaroscope could also provide realtime image adaptation, image storage and reproduction, further analysis and measurement of the parameters observed [18].

The patient preparation for capillaroscopy should try to elude factors with impact on microcirculation like microtrauma, onychophagia, smoking, nail lacquer or artificial nails [8]. A complete preparation for capillaroscopy includes hand washing, avoiding caffeine and smoking 6 hours before examination, and avoiding to remove the nail cuticles [19]. Giving up manicure for 15 days will avoid microtrauma of cuticula with subsequent hemorrhages and edema [17].

Table 1

Nailfold capillaroscopy indications

\begin{tabular}{|c|}
\hline Indications \\
\hline - All patients with Raynaud phenomenon \\
\hline - Differential diagnosis: primary vs secondary Raynaud phenomenon \\
\hline - All patients with Systemic sclerosis \\
\hline - Diagnostic approach in systemic sclerosis \\
\hline - Staging in systemic sclerosis \\
\hline - Follow-up/ treatment response of patients with systemic sclerosis \\
\hline - Evaluation of patients with Scleroderma spectrum disorders \\
\hline$\cdot 2$ Dermatomyositis (DM) \\
\hline - Mixed connective tissue disease (MCTD) \\
\hline$\bullet$ Undifferentiated connective tissues disease (UCTD) \\
\hline - Differential diagnosis (e.g. Dermatomyositis versus Polymyositis) \\
\hline - Follow-up/ treatment response \\
\hline - Need of screening for pulmonary involvement \\
\hline - Diagnostic approach of idiopathic interstitial lung disease \\
\hline After Cutolo M et al. [5], Cutolo M et al. [16], and Chojnowski MM et al. [30] \\
\hline
\end{tabular}


Also, acclimatization of the patients before examination is very important, as cold-induced vasoconstriction impede the capillaries visualization $[5,8]$. It is recommended for the patient to stay in a room with temperature $20-25^{\circ}$ for at least 15 minutes before the NFC exam starts [17]. For examination, the hands are put on a table, approximately at the heart level. All fingers are examined, with the exception of the thumb [17].

The direct contact between the videocapillaroscope optic probe and the nailfold bed is done after applying neutral (vegetal) oil on the examined area, thus avoiding light reflection on the skin surface $[19,17,20]$.

The optic probe is positioned over the nailfold and should exert no pressure [5]. Excessive pressure may interfere with blood flow by compressing the capillaries, consecutively producing loss of capillary visibility, so that the focus area might look falsely avascular [17]. This should be correctly assessed and differentiated from real avascular areas, "deserted areas" determined by pathologic capillary loss in SSc or related pathologies [17]. It is recommended to take two to four images of each nailfold after focusing on the distal layer of capillaries [19].

From the eight fingers examined, the fourth and fifth fingers most frequently provide clinically relevant information in both visibility and pathologic findings [19]. When a complete examination cannot be performed, the evaluation of both ring fingers is considered most relevant for diagnosis, the "best two fingers combination" [10]. The correct preparation of the capillaroscopic exam significantly reduces technical errors [17]. Overall, an NFC exam should last around 15-30 minutes [19].

Efforts are done to have automated systems for capillaries evaluation, involving image-processing software, allowing automatic extraction of quantitative features, such as the automated absolute capillary number counting [21, 22].

\section{CAPILLAROSCOPY PARAMETERS AND DEFINITIONS}

The parameters analyzed during the NFC examination include skin transparency, venous plexus, the capillaries' characteristics, namely distribution, density, length and diameter, presence of pathologic changes like microhemorrhages, neoangiogenesis, and blood flow characteristics (see Table 2) [8].

Visibility is mainly driven by skin transparency [8] and might be modified by factors like skin color, hyperkeratosis, edema and fibrosis [4]. The subpapillary venous plexus is situated deep in the nailfold base and drains all capillary venous loops [19]. The subpapillary venous plexus is visible in about $30 \%$ of subjects [1]. The blood flow is commonly faster in the subpapillary plexus than in capillaries [19].

Table 2

Parameters and definitions in nailfold capillaroscopy

\begin{tabular}{|c|c|}
\hline Parameter & Definition \\
\hline Visibility/ Skin transparency & The interface that capillaries view. \\
\hline Subpapillary venous plexus & Vascular network at the nailfold base. \\
\hline Capillary orientation & Capillaries direction in report to the skin surface. \\
\hline Capillary density & Number of capillaries/ $1 \mathrm{~mm}$. \\
\hline Capillary morphology & The shape of each individual capillary. \\
\hline Capillary length & $\begin{array}{l}\text { Distance between the capillary apex and the point where the capillary loop is no } \\
\text { longer visible. }\end{array}$ \\
\hline Capillary diameter & Width of the arterial (afferent), apical, venous (efferent) loop (especially apical loop). \\
\hline Pericapillary edema & Pericapillary increase of interstitial fluid. \\
\hline Microhemorrhages & Dark areas of hemosiderin on the nailfold capillary bed due to the capillary wall rupture. \\
\hline Neoangiogenesis & Abnormal shapes (other shapes than hairpin, tortuous, or crossing). \\
\hline Blood flow characteristics & Regular erythrocytes column, slowed down. \\
\hline
\end{tabular}


The capillaries are usually distributed homogeneously and regularly in horizontal lines, which leads to a palisade[1] or comb-like structure [16] and the distal row capillaries are perpendicular to the nail edge [1] (see Figure 1). For each examined finger, capillary density is defined by the number of capillary loops per millimeter length of the distal row $[1,19]$. The mean density in all fingers can be calculated [23]. The capillaries density is

$1 a$.

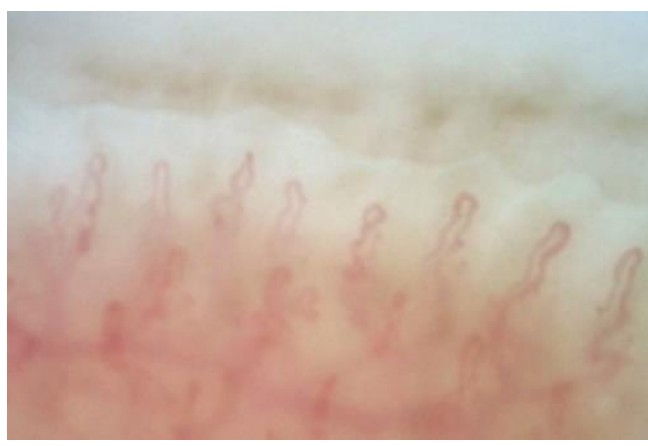

1c.

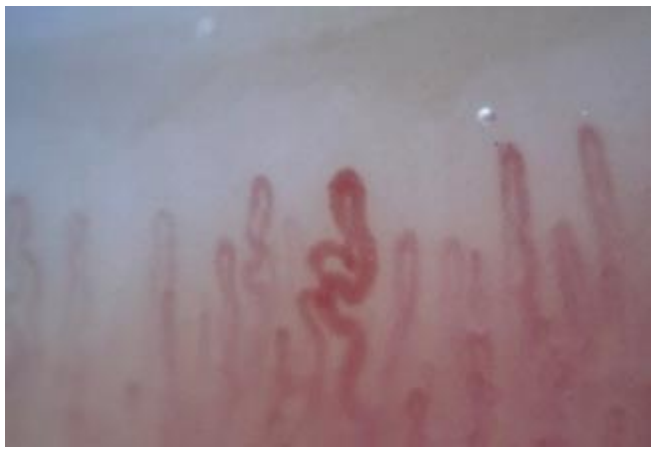

one of the most important and reliable capillaroscopic parameters [15] as it might predict the development of an underlying connective tissue disease [1]. A capillaryes density higher than 7 capillaries $/ \mathrm{mm}$ is considered normal $[15,19]$. Capillary density was the first NFC parameter for which automated counting systems were developed, automated count of the nailfold capillary number (AUTOCAPI) [22].

$1 b$.

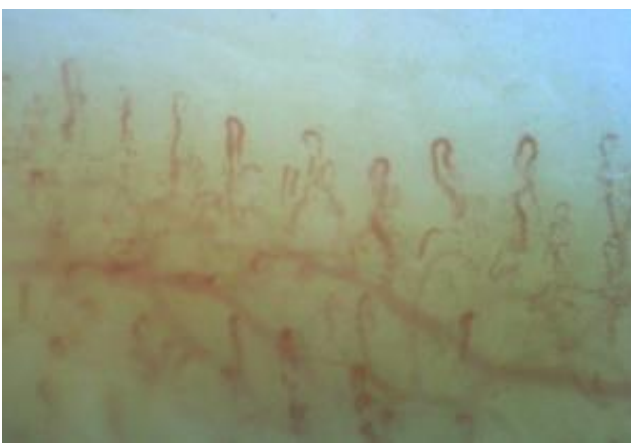

1d.

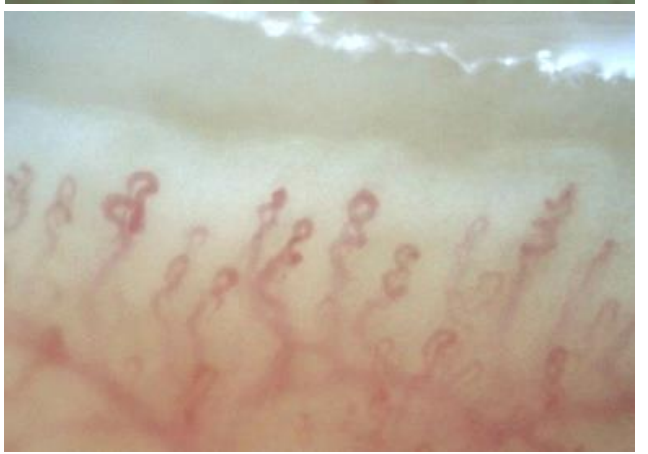

Figure 1. Normal shapes: 1a. hairpin; 1b. crossed capillaries; 1c. ectasia; 1d. meandering.

The morphology of each capillary loop is described and analyzed separately. In healthy subjects, nailfold capillaries have a hairpin shape, but variations like tortuous or crossed capillaries can also be seen. Meandering capillaries have loops crossed upon themselves several times [1]. In late stages of scleroderma spectrum disorders (SSD), twisted and bushy capillaries are found as a result of neoangiogenesis [1,12] (see Table 3; Figure 2).

\section{Table 3}

Abnormalities described in nailfold capillaroscopy

\begin{tabular}{|c|c|c|}
\hline Type & Synonyms & Description \\
\hline Ectasia & $\begin{array}{l}\text { Ectatic loop } \\
\text { Loop enlargement } \\
\text { Dilatated capillary }\end{array}$ & $\begin{array}{l}\text { Moderately enlarged limps, between } 4 \text { and } 10 \text { normal size. } \\
\text { Diameter greater than } 20 \mu \mathrm{m} \text { for the venous and } 15 \mu \mathrm{m} \text { for the } \\
\text { arterial loop, but less than } 50 \mu \mathrm{m}\end{array}$ \\
\hline \multirow[t]{2}{*}{ Non-specific variations } & Tortuous capillaries & Serpentine branches, without crossing each other \\
\hline & Crossed capillaries & Branches that cross more than one time \\
\hline Meandering capillaries & Meandering loops & Loops crossed upon themselves several times \\
\hline Bizarre capillaries & Bizarre loops & $\begin{array}{l}\text { Atypical non-classifiable morphology, rare forms that cannot } \\
\text { be integrate as hairpin, tortuous, or crossed. }\end{array}$ \\
\hline $\begin{array}{l}\text { After Bertolazzi C et c } \\
\text { Cutolo M et al. [5]. }\end{array}$ & 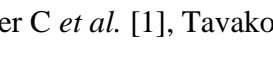 & [19], Cutolo M et al. [16], and \\
\hline
\end{tabular}


2a.

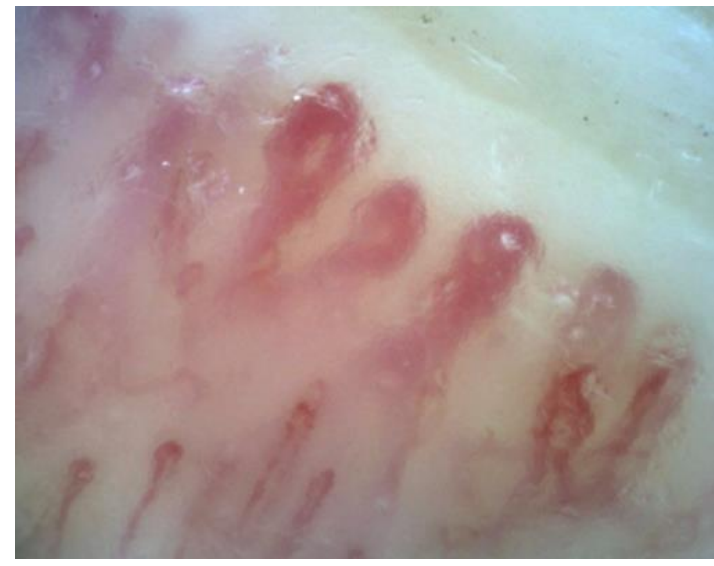

2c.

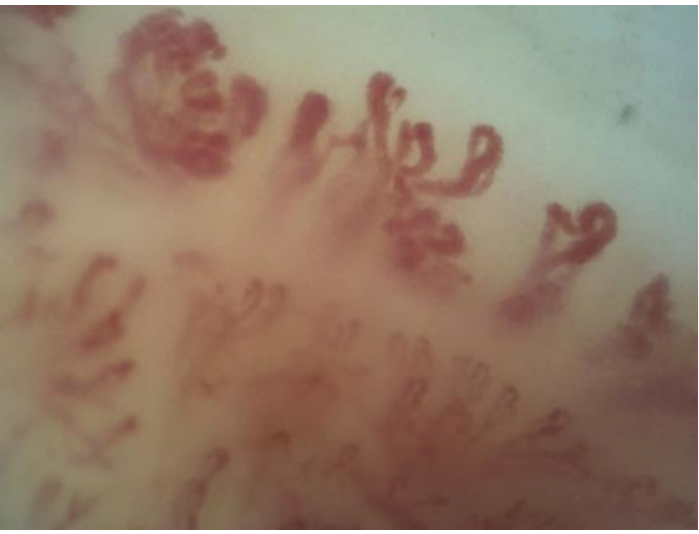

2b.

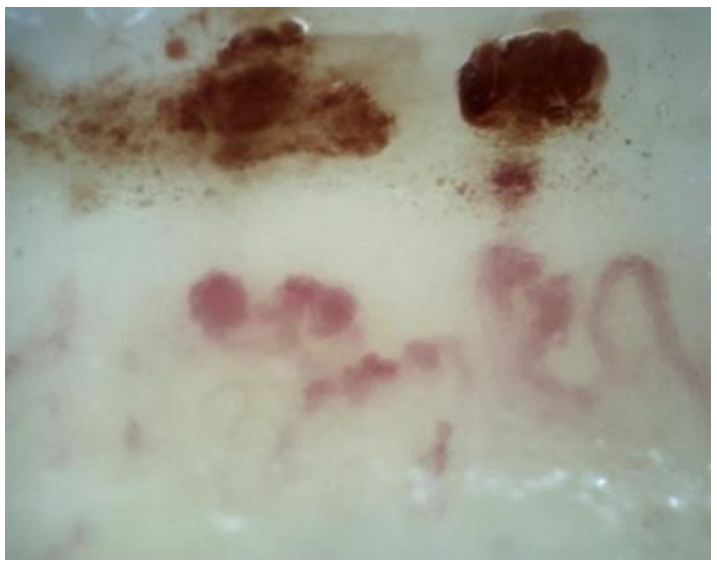

2d.

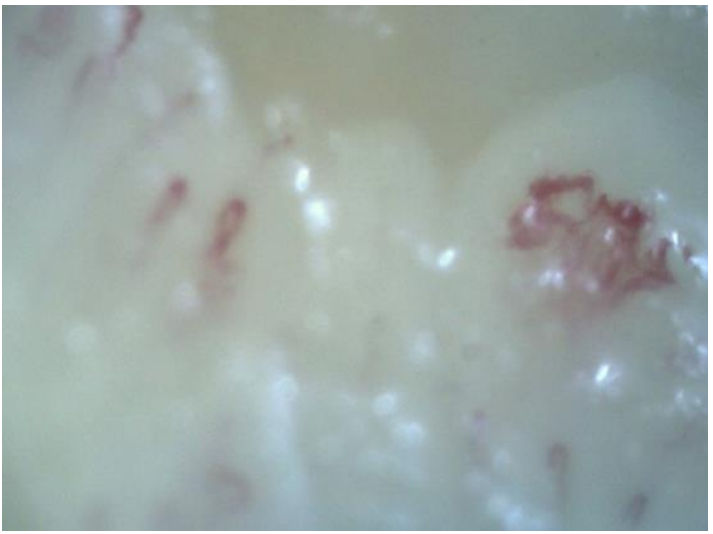

Figure 2. Pathologic capillaroscopic findings: 2a. giant capillaries; 2b. microhemorrhages; 2c. neoangiogenesis; $2 \mathrm{~d}$. avascular areas

The capillary length or height is not regularly performed in clinical practice, being less relevant for a final diagnosis. The capillary length is measured between the capillary loop apex and the region where the loop is no longer visible [19] and capillaries are so classified as short or long [23]. It is to note that the capillaries length of the fourth and fifth fingers is longer than that in other fingers [19]. However, the capillaries length is variable (some authors consider values higher than $300 \mu \mathrm{m}$ abnormal) and less useful for diagnosis in clinical practice [24].

The evaluation of capillary diameter is an essential part of the NFC examination as it allows identification of giant capillaries, a marker of the scleroderma pattern. The capillary width is measured at the widest section [19] and the mean diameter is obtained by the means of three consecutive loops, giant capillaries being defined by diameter higher than $50 \mu \mathrm{m}$ [19]. The diameters of the afferent arterial side, apical loop, and also of the efferent venous loop are measured [1]. If only one measure is done, the apical loop is preferred. The interpeak capillaries refers to the intercapillaries distance, between two successive capillaries [19].
Moreover, pericapillary edema might be described like flu contour surrounding the capillary loop. The pericapillary edema is normally absent [10]. However, the visibility is influenced by several factors as already mentioned and it is difficult to discriminate the flu contour from other causes of reduce visibility or diminished sharpness.

It was estimated that only about $40 \%$ of general population has a pattern with completely normal capillaries, while in 50\% minor abnormalities are found [17]. Giant capillaries, microhemorrhages, avascular areas or neoangiogenesis are not described in healthy subjects, but as part of the scleroderma pattern and will be detailed later [12] (see Table 4).

Beside the qualitative NFC exam that allows the identification and description of specific parameters, semi-quantitative and quantitative NFC methods may provide more accurate assessments. Parameters like capillary density, capillary diameter, and a number of various capillary abnormalities can be quantitatively assessed $[15,16]$ by counting the number of each on either side at $1 \mathrm{~mm}$ of the reference point on all fingers, divided by the capillaries sum score [25]. The first semi-quantitative and quantitative approaches were used to differential diagnosis of early SSc from other 
rheumatic diseases [26]. The degree of the capillary enlargement was graded as follows: $0=$ normal, 1=borderline, more than 2 times enlargement, $3=$ extremely enlarged, more than 4 times enlargement [26]. Also, the capillary loss was graded as follows: $\mathrm{A}=$ no capillary loss, $\mathrm{B}=$ rare capillary loss, $\mathrm{C}=$ =moderate capillary loss, $\mathrm{D}=$ extensive capillary loss [26]. The most used semiquantitative rating scale is as follows: $0=$ no changes, $1=$ less than $33 \%$ capillary alterations/ reduction, $2=33-66 \%$ of capillary alterations/ reduction, $3=$ more than $66 \%$ alterations or reduction $/ \mathrm{mm}$ were tested to assess the capillaries number, enlarged and giant capillaries, microhemorrhages, and ramified capillaries in NFC [27].

\section{NORMAL CAPILLAROSCOPY PATTERN - HEALTHY SUBJECTS}

The qualitative NFC assessment in healthy subjects shows homogeneous capillaries distribution in the field examined. Most frequently, the capillaries are stand perpendicularly to the nail edge [1,11]. The terminal row of capillaries is arrange in parallel fashion and grant a full length description of the capillary [11]. Under the rows of capillaries, the subpapillary venous plexus might be seen and appears of greater diameter [17].

Beside the hairpin, "U" shape morphology, some other shapes might be display in the frame of the normal pattern. The morphology of each normal capillary loop analyzed separately looks like hairpin [1,5,16,11], English letter "U" upside down [19]. The arterial afferent loop is thinner than the venous efferent one [1] (see Figure 1). Besides the hairpin shape, other two discrete abnormalities, nonspecific variations are recognized for the normal pattern: tortuous (the loops undulate but do not cross) and crossing (loops crossed once or twice) capillaries that together with the hairpin shape are considered normal [15]. Besides these three shapes (hairpin, tortuous, crossing) all the other are defined as abnormal morphologies [15] (see Table 2).

\section{Table 4}

Major pathological hallmarks of the scleroderma pattern observed in nailfold capillaroscopy

\begin{tabular}{|l|l|l|}
\hline Parameter & Synonyms & Description \\
\hline Giant capillary & Mega capillary & $\begin{array}{l}\text { Loop diameter }>50 \mu \mathrm{m} \\
\text { (afferent, apical, efferent) }\end{array}$ \\
\hline Microhemorrhages & Micro bleedings & $\begin{array}{l}\text { Hemosiderin deposits seen as dark spots } \\
\text { Erythrocytes microvascular extravasation }\end{array}$ \\
\hline Avascular area & $\begin{array}{l}\text { Loss of } \geq 2 \text { contiguous capillaries } \\
\text { Distance } \geq 500 \mu \mathrm{m} \text { between adjacent capillaries } \\
\text { Less }<30 \text { capillaries/ 5 mm }\end{array}$ \\
\hline Neoangiogenesis (Ramifications) & $\begin{array}{l}\text { Capillaries loss } \\
\text { Reduced density } \\
\text { Deletion areas }\end{array}$ & $\begin{array}{l}\text { New vascular formation } \\
\text { Highly heterogeneous shape } \\
\text { Branched capillaries }\end{array}$ \\
\hline
\end{tabular}

After Bertolazzi C [4], Sebastiani M et al. [43], Tavakol ME et al. [19], Cutolo M et al. [16], After Cutolo $\mathrm{M}$ et al. [5], and Faggioli $\mathrm{P}$ et al. [8].

Ingegnoli $\mathrm{F}$ et al. described the morphological aspects of the capillaries as hairpin shaped loop, loops with one cross, loops with more than two intersections, as well as meandering loops and proposed three main capillaroscopic patterns for normal variations found in healthy subjects, namely first one "normal" with 2-5 U-shaped loops $/ \mathrm{mm}$ and maximum 2 tortuous loops $/ \mathrm{mm}$; the second one, named also "perfect normal" which consists of more or equal than $5 \mathrm{U}$-shaped loops- $/ \mathrm{mm}$, and the third one, "unusual normal" consisting in at least any of the following: one meandering, one bushy loop, one microhemorrhage, or more than 4 crossed loops/mm [18]. Therefore, unusual capillaries like intercrossed capillaries, tortuous capillaries, elongated capillaries, or disorganization of the capillaries might occur even in subjects without underlying SSD [17].

Counting the number of capillaries reported to distance (per $\mathrm{mm}$ ) is important for defining normality [18]. Different authors defined various limits for the normal capillaries density, like 9-14 (average 10) capillaries/ mm [16], 7-10 capillaries/ $\mathrm{mm}$ [18], 9-13 capillaries/ $\mathrm{mm}$ [8], 6-14 capillaries/mm [17], 7-12 capillaries [28]. A recent standardization of the EULAR study group for 
microcirculation in rheumatic diseases stated that more than 7 capillaries/ mm define normal density [15] (see Table 5).

Similarly, the reports for capillaries loops diameter or length are not uniform. The ectasia was initially defined as having 4-9 times higher, while the giant capillaries more than 10 times higher than normal diameter [1]. Further, the normal diameter of the afferent branch of 6-19 $\mu \mathrm{m}$ and 8-20 $\mu \mathrm{m}$ for the efferent branch, with diameters of more than 50 $\mu \mathrm{m}$ defining the mega/ giant capillaries, $[1,8,17]$. By consensus, it was recently established that a diameter of maximum $20 \mu \mathrm{m}$ for normal diameter and $50 \mu \mathrm{m}$ for ectasia [15]. The loop length is representing the visible part of the capillaries and normal ranges were reported by some authors of 200-250 $\mu \mathrm{m}$ [17], but also up to $500 \mu \mathrm{m}[8,18]$, while elongated capillaries have length of more than $300 \mu \mathrm{m}, 500 \mu \mathrm{m}$ or even $700 \mu \mathrm{m}$ [29].

Microhemorrhages might be seen in healthy individuals in case of local trauma in which its position is closer to the nail and not related to a giant capillary recently collapsed [1].

\section{PRIMARY VERSUS SECONDARY RAYNAUD'S PHENOMENON}

RP is characterized by the change of color fingers that evolves in three stages (pallor, cyanosis, rubor) and reflects reversible ischemia secondary to vasospastic events commonly triggered by cold or stress [1]. RP is found in about $2-9 \%$ of the general population [17].

\section{Table 5}

Capillaroscopic aspect in healthy subjects

\begin{tabular}{|l|l|}
\hline Parameter & Description \\
\hline Skin transparency & Allows a good visualization of the capillaries \\
\hline Subpapillary venous plexus & Visible in up to 30\% of healthy individuals \\
\hline General view & Homogeneously sized, regularly arranged \\
\hline Capillary orientation & Straight, parallel fashion, usually perpendicular to the nailfold \\
\hline Capillary density & Number of capillaries over 1mm nailfold, more than 7 capillaries/mm \\
\hline Capillary morphology & $\begin{array}{c}\text { Inverted "U", hairpin shape, but also tortuous and/ or crossing capillaries } \\
\text { (nonspecific variations) }\end{array}$ \\
\hline Capillary length & Less than 300 $\mu \mathrm{m}$ \\
\hline Capillary diameter & Less than $20 \mu \mathrm{m}$ for each loop (afferent, apical, efferent) \\
\hline Pericapillary edema & Absent \\
\hline Hemorrhages & Absent (occasionally observed after microtrauma) \\
\hline Giant capillary & Absent \\
\hline Neoangiogenesis & Absent \\
\hline Blood flow characteristics & Dynamic, no stasis \\
\hline After Kayser C et al. [1], Chojnowski MM et al. [30], Cutolo M et al. [5], and Smith V et al. [15]. \\
\hline
\end{tabular}

The RP is classified as primary (idiopathic) or secondary [1]; setting in which the RP may be associated to systemic autoimmune diseases [17]. Primary RP appears usually in young people around 14 years onset age, in symmetric form with rather mild episodes that are not accompanied by trophic complications [1]. Secondary RP has often onset after 30 years, develops more intense and painful episodes that might further complicate with ischemic lesions [1].

$\mathrm{RP}$ is the most frequent indication for performing NFC [16]. In patients with primary, idiopathic RP, the NFC finds virtually no changes.
Moreover, the normal pattern in NFC is backed by lack of other symptoms relevant of connective tissue diseases as well as by normal ranges for acute phase reactants [30].

NFC should be carried out in all patients with RP $[5,16]$ given that up to $15 \%$ of all patients with initially idiopathic RP might develop SSc features within 3 years [16], but there is no consensus on the frequency of this examination (some authors suggested yearly NFC in patients with RP) $[5,16]$. Between the parameters analyzed, the absence of capillaries with diameter higher than $30 \mu \mathrm{m}$ correlated with low risk of SSc development [15]. 
Capillaroscopic indexes to predict the transition from primary to secondary RP are discussed. Therefore, based on six variables, namely capillaries density, branching, enlarged and giant loops, capillary disorganization, and microhemorrhages, an index named PRINCE (Prognostic Index for Nailfold Capillaroscopic Examination) was design to predict 5-year transition from isolated RP to secondary to SSD' RP [31]. Further, using also the antinuclear antibodies (ANA) status, Ingegnoli et al. [32] classified three categories of risk for the progression from RP to SSc: low risk $(<10 \%)$ involving mean number of capillaries greater than $8.4 / \mathrm{mm}$ or less than $8.4 / \mathrm{mm}$ and negatives ANA, intermediate risk (10-50\%), and high risk (> 50\%) with low capillaries density associated with ANA positivity [20,32]. This algorithm was called PRINCESS (Prognostic Rule-based Instructions using Nailfold Capillaroscopy Examination and Scleroderma-related Serology) [20,32].

In patients with already defined SSD, the RP occurrence might predict the development of local complications, severe organ involvements like pulmonary arterial hypertension, and more severe prognosis [17]. In one study including 586 patients with RP followed for 3,197 person-years, $12.6 \%$ developed definite SSc. The enlarged capillaries, capillary loss, as well as the SSc-specific autoantibodies independently predicted a definite SSc [33].

\section{SYSTEMIC SCLEROSIS}

SSc is the only pathology that can be preclinically predicted by combination of serology and capillaroscopy findings [16]. In SSc, specific NFC changes appear and further evolve in a defined sequence that was named scleroderma pattern [30], identified in 90-95\% SSc patients $[30,34]$, one of the reasons for which NFC is included in the 2013 ACR/ EULAR classification criteria for SSc [13].

NFC enables not only the early diagnosis of SSc, but also prediction of disease progression and of complications occurrence during follow-up [35]. The "very early" diagnosis of SSc (VEDOSS) criteria contain three domains with seven items. NFC scleroderma pattern together with RP, puffy fingers, ANA, and SSc-specific antibodies are part of the "very early" diagnosis of SSc [36].

The specific NFC findings suggestive for SSc are the giant capillary and the loss of capillary, that are essential for the SSc diagnosis, followed by microhemorrhages and finally neo-vascularization [16,37] (see Tables 4 and 6).

\section{Table 6}

Capillaroscopic patterns for scleroderma microangiopathy

\begin{tabular}{|c|c|c|}
\hline Pattern & Description & \\
\hline $\mathbf{E}$-early & $\begin{array}{l}\text { No evident loss of capillaries } \\
\text { Preserve architecture } \\
\text { Few giant capillaries } \\
\text { Few microhemorrhages }\end{array}$ & $\begin{array}{l}\text { Density } \geq 7 \text { capillaries } / \mathrm{mm} \\
\text { Homogeneous distribution } \\
\text { Diameter (apical, but any/all loops) } \geq 50 \mu \mathrm{m} \\
\text { Dark spots }\end{array}$ \\
\hline A-active & $\begin{array}{l}\text { Moderate loss of capillaries } \\
\text { Frequent giant capillaries } \\
\text { Frequent microhemorrhages } \\
\text { Abnormal morphology } \\
\end{array}$ & $\begin{array}{l}\text { Lowered density } 4-6 \text { capillaries/ } \mathrm{mm} \\
\text { Diameter (apical, but any/all loops) } \geq 50 \mu \mathrm{m} \\
\text { Dark spots } \\
\text { Non-specific variations: tortuous/ crossing }\end{array}$ \\
\hline $\mathbf{L}$-late & $\begin{array}{l}\text { Important loss of capillaries } \\
\text { Severe architecture damage } \\
\text { Abnormal morphology } \\
\text { Neoangiogenesis } \\
\text { Almost absent microhemorrhages } \\
\text { Almost absent giant capillaries }\end{array}$ & $\begin{array}{l}\text { Even lower density } \leq 3 \text { capillaries/ } \mathrm{mm} \text { (avascularization) } \\
\text { Intense disorganization } \\
\text { Frequent abnormalities, highly heterogeneous shapes, } \\
\text { numerous ramified and bushy capillaries }\end{array}$ \\
\hline
\end{tabular}

The giant capillary is the earliest SSc feature and one single giant capillary is suggestive for SSc development [16]. The loop enlargement is symmetrical, both arterial and venous loops are affected and reflects the endothelial cell array damage with micro-vessel wall alteration [16]
After the capillaries collapse and red blood cells extravasation, the loss of capillaries occurs. The diminished capillaries density determines local hypoxia with subsequent locally increased growth factors and further stimulation of new vessels organization. Neovascularization is 
described as capillaries heterogeneity with abnormal morphology, twisted and bushy capillaries [16] (see Figure 2).

The enlarged capillary diameter is therefore the first NFC marker for SSc. The ongoing standards stat normal size capillaries for diameters having up to $20 \mu \mathrm{m}$, while for giant capillaries loop diameter larger than $50 \mu \mathrm{m}$ [1]. Capillaries with loops between 20 and $50 \mu \mathrm{m}$ are described as enlarged capillaries [1]. After reaching maximum dimensions, the capillaries collapse and produce microhemorrhages that are visible at the nailfold capillary bed as darker areas [1]. The differential diagnosis for microhemorrhages must be done with lesions due to microtrauma or capillary thromboses [24]. The shape of capillary thrombosis mirrors the capillary loop [24]. Further, the capillary loss is defined based on the capillaries density, namely lower than 7 capillaries/mm [1]. The vasculopathy progression might be accompanied by clinical overt disease manifestations [37]. Avascular areas may be focal or diffuse; more than $500 \mu \mathrm{m}$ between two successive loops is defined as a diffuse avascular area (devascularization) [1]. Neoagiogenesis is determined by local hypoxia, appearance of new vascularization with highly heterogeneous shape and multiple branches [1] (see Table 4).

As we already mentioned, Cutolo $\mathrm{M}$ et al. described three evolutive capillaroscopic patterns, able to quantify and monitor the microvascular damage progression in SSc patients [10,38], namely E (early), A (active), and L (late) pattern [10] (see Table 6).

Capillary density seems to be the most reliable parameter, useful for SSc monitoring [15]. In the early capillaroscopic pattern, there is never observed lower density [15]. On the contrary, the next patterns, the active ( $4-6$ capillaries/ $\mathrm{mm}$ ) and late ( $\leq 3$ capillaries/ $\mathrm{mm}$ ) patterns, always present lowered density, meaning less than 7 capillaries/ $\mathrm{mm}$ [15]. This simplification as "always/ never" was considered for an easier application in clinical practice [15]. The giant capillaries are specific for the early pattern, while avascularity for the late pattern [15]. Neoangiogenesis in the feature of advanced microvascular involvement, late SSc stages [16].

A fast-tracking algorithm was developed to discriminate between scleroderma and nonscleroderma pattern. The easy rule of thumb of the fast algorithm includes capillary density and the presence of giant capillaries [39]. The presence of giant capillaries allows distinction between scleroderma and non-scleroderma pattern with over $95.6 \%$ specificity [39].

Further, the NFC changes observed might be linked to specific SSc features like specific SSc involvements [20]. Therefore, the degree of capillaries loss correlates with pulmonary arterial hypertension severity [40] and survival rates in SSc $[28,41]$. SSc patients with pulmonary interstitial disease presented lower median capillary density and higher degree of neoangiogenesis [42]. SSc late pattern was associated with lower forced vital capacity (FVC) [42] and the number of giant capillaries with reduced diffusion capacity of the lung [42]. However, the clinical associations that have been described for NFC are not proved to be clinical reliable, each case should be always considered separately.

Several NFC indexes were developed for prediction in SSc. The capillaroscopic skin ulcer risk index (CSURI) was developed to predict the onset of digital ulcerations in SSc patients [43]. CSURI integrates the total number of capillaries, the maximum size of the loop diameter as well as the number of mega capillaries in order to predict de skin ulcer occurrence in 3-month follow-up period [43]. A semiquantitative rating scale, named the "microangiopathy evolution score" was also proposed to assess the progression of the vascular damage. This scale sum three items, namely the loss of capillaries, disorganization of the microvascular array and the capillary ramifications [38]. The NEMO score that assesses the cumulative number of microhaemorrhages and microthromboses is used as indicator of the steady state level of disease activity in SSc patients and also the overtime changes in disease activity [44]. Further, a composite score, Clinical data, Imaging and Patient history (CIP-DUS) for digital ulcers occurrence over 12-months follow-up period was proposed. CIP-DUS combines clinical data and disease history with NFC, colour Doppler ultrasonography and fluorescence optical imaging [45].

\section{SCLERODERMA SPECTRUM DISORDERS}

SSD are a heterogeneous group of pathologies, for which disease-specific features 
were defined, including undifferentiated connective tissue disease (UTCD), mixed connective tissue disease (MCTD), and dermatomyositis (DM). The microvascular alterations found in SSD are alike the ones found in SSc, (see Table 7).

\section{Table 7}

Capillaroscopy findings in other than systemic sclerosis pathologies

\begin{tabular}{|c|c|}
\hline Pathology & Capillaroscopy findings description \\
\hline \multicolumn{2}{|l|}{ Scleroderma spectrum disorders } \\
\hline Dermatomyositis (DM) & $\begin{array}{l}\text { Important capillaries abnormalities: giant capillaries, ramified } \\
\text { capillaries, increase neoangiogenesis } \\
\text { Scleroderma pattern (most cases) }\end{array}$ \\
\hline Mixed connective tissue disease (MCTD) & $\begin{array}{l}\text { Presence of enlarged or giant loops, avascular areas, nonspecific } \\
\text { abnormalities, or borderline lesions } \\
\text { Scleroderma pattern (most cases) }\end{array}$ \\
\hline \multicolumn{2}{|l|}{ Non-scleroderma spectrum disorders } \\
\hline Systemic lupus erythematosus (SLE) & $\begin{array}{l}\text { Increased capillaries tortuosity } \\
\text { Meandering loops } \\
\text { Increased capillaries length } \\
\text { Rarely, focal area of capillaries loss } \\
\text { In some, increased subpapillary venous plexus visibility }\end{array}$ \\
\hline Antiphospholipid syndrome (APS) & $\begin{array}{l}\text { Symmetric microhemorrhages (especially for secondary APS) } \\
\text { Variations of loop lengths (especially primary APS) }\end{array}$ \\
\hline Sjogren's syndrome (SS) & $\begin{array}{l}\text { Tortuous and irregular capillaries } \\
\text { In some, increased subpapillary venous plexus visibility }\end{array}$ \\
\hline Rheumatoid arthritis (RA) & $\begin{array}{l}\text { Most frequent, increased subpapillary venous plexus visibility } \\
\text { In some, increased capillaries tortuosity } \\
\text { In some, increased capillaries length }\end{array}$ \\
\hline \multicolumn{2}{|c|}{$\begin{array}{l}\text { After Kayser C et al. [1], Chojnowski MM et al. [30], and Lin K-M et al. [24]. } \\
\text { * the attempts of defining nailfold capillaroscopic patterns or specific finding in other than systemic sclerosis pathologies failed } \\
\text { until now }\end{array}$} \\
\hline
\end{tabular}

\subsection{Undifferentiated connective tissue disease}

UCTD refers to connective disorders that have incomplete clinical features [46]. In one research, in 98 patients with UCTD followed up for 11 years, $24 \%$ entered in remission while $14 \%$ developed a definite connective tissue disease [47]. Alongside with cytopenia and positives ANA, the progressive changes observed in NFC were predictors for a definite connective tissue disease development [47]. 20\% UCTD patients present nonspecific NFC findings [8]. When compared to early SSc, $48.7 \%$ versus $37.8 \%$ had functional alterations, while $92.0 \%$ versus $17.1 \%$ developed definitive SSc diagnosis within five years of follow-up [48].

\subsection{Mixed connective tissue disease}

MCTD is systemic autoimmune disease characterized by high anti-U1-RNP titers. The anti-U1-RNP positivity in other CTD than MCTD was associated with NFC abnormalities [49]. The NFC findings in MCTD microangiopathy have a dynamic evolution [50], the NFC changes progress [51] with significant decrease over time of the moderate and severe avascular areas [50]. The term frequently used in MCTD is "scleroderma like" NFC abnormalities, and 
a specific MCTD capillaroscopic pattern was not defined yet [52].

Scleroderma pattern was found in 54\% [53], $63.6 \%$ [54], 70\% [50,52], and up to $82 \%$ [53] of MCTD patients. $72.7 \%$ of MCTD patients might have bushy capillaries [54]. Besides bushy capillaries, the most frequent encountered parameters are the capillaries dilatations [8].

MCTD patients with scleroderma pattern are younger than those with other capillaroscopic patterns [50]. When compared to SLE patients, the NFC in MCTD demonstrates higher capillaries loss and more frequent scleroderma pattern or bushy capillaries [54]. When compared to SSc, the scleroderma pattern was less frequent and bushy capillaries were more frequent encountered [54].

The pulmonary involvement in MCTD might corelate to the NFC findings. Avascular areas in NFC were more frequent in SSc with interstitial lung disease [50], while pulmonary arterial hypertension appears more frequent in MCTD with RP and NFC changes [55]. Another study showed that the number of giant capillaries was predictor for the interstitial lung disease co-existence [56]. The pulmonary ground-glass opacity areas correspond to inflammatory lung biopsies and might be related to the capillaroscopy findings [50]. Therefore, NFC should be considered in all patients with MCTD and further, scleroderma type findings should raise concern on MCTD pulmonary involvement [56]. Some authors described improvement of the NFC microvascular pattern under immunesuppressive treatment in both SSc and MCTD [57], but more data are needed to sustain these observations.

\subsection{Dermatomyositis}

The pathogenic pathways involved in DM implies a complement-mediated microangiopathy that has the endothelium as target, with inflammatory processes especially in endomysia [17]. The spectrum of autoimmune myopathy is complex and so differentiating between PM and DM has lost significance [58]. However, NFC exam might help the differential diagnosis between DM and PM. The difference between DM and polymyositis (PM) in NFC reflects the underlying pathogenic processes, respectively microangiopathy versus autoimmune cytotoxic reaction centered by the T cell [30]. One systematic review that analyzed 27 selected researches from 540 publications, reported NFC alterations in $63.6 \%$ to $88.9 \% \mathrm{DM}$ and in up to $32 \%$ with PM [34]. Of these, scleroderma pattern was described in 27 to $57 \%$ patients [34]. Besides "scleroderma pattern" the NFC alterations found in DM are named "scleroderma-like pattern", "scleroderma-dermatomyositis pattern", undefined "alterations" or "vasculopathy" [34].

In DM, at least two of the following modifications: capillaries enlargement, capillaries lost, normal distribution disorganization, bushy capillaries, twisted enlarged capillaries, or hemorrhages are more frequent than in general population [8], the ectasia and bushy capillaries being the most frequent [8]. Similar to SSc, giant capillaries are more frequent in patients with less than 6 months disease durations, while ramified capillaries in longstanding disease [34]. The number of enlarged capillaries is higher in DM patients with pulmonary involvement, while enlarged capillaries and loss of capillaries are related to RP and arthritis [34]. NFC changes are usually remitting together with the cutaneous ones. The capillaroscopic pattern is more rapidly changing in DM when compared to SSc and neoangiogenesis is an indicator of longstanding disease [34].

\section{OTHER THAN SDS RHEUMATOLOGIC PATHOLOGIES}

In other connective tissue diseases than SSD, the capillaroscopic pattern might be normal, with nonspecific findings, or borderline changes [16]. There are defined two types of borderline capillaroscopic findings: high prevalence of abnormal shapes (neoangiogenesis, with the exception of normal hairpin, tortuous, crossing) or concomitance of microhemorrhages, abnormal shapes (neonagiogenesis), and size variations [16].

\subsection{Antiphospholipid syndrome}

The vascular lesions observed in the antiphospholipid syndrome (APS) are based on a non-inflammatory vasculopathy [59]. The NFC findings in APS are not specific and a characteristic patter was not defined yet. When compared to controls, APS patients presented significantly smaller capillaries diameters ( for the 
afferent, apical or efferent loop) [59]. While the capillaries density did not differ between controls and patients with primary APS, the frequency of bushy capillaries, crossing capillaries and other morphological alterations was more frequent in the later [59]. The NFC exam was done comparatively, trying to find out features that might differentiate primary APS of secondary to SLE APS cases, but failed to be found [60],[61]. Also, splinter hemorrhages are specifically described in APS.

One important aspect in APS patients is capillary thrombosis that might be falsely interpret as microhemorrhages [62]. In microvascular thrombosis, the dark zone takes the shape of the capillary loop [62]. The NFC changes seems to be related to the prevalence of the large vessels thrombotic events [60].

In patients with other than SSc rheumatologic diseases, microhemorrhages were associated with anticardiolipin (aCL) and anti-beta2-glycoprotein I (aß2GPI) antibodies [63]. Also, in another research, from 343 patients with various rheumatic diseases, microhemorrhages were found in 149 NFC exams were correlated with the APS serology in these patients [64].

\subsection{Systemic lupus erythematosus}

NFC abnormalities are described in around $30 \%$ SLE cases [65]. A systematic review regarding NFC approach in SLE included a total of 14 original articles [29]. The authors described in SLE: normal pattern (with regular distribution of typical hairpin capillaries), non-specific pattern (including abnormalities that do not fulfill the scleroderma pattern definition), and scleroderma pattern (giant capillaries, hemorrhages, avascularity) [29]. Five of the studies included in one systematic review tried to define a specific SLE pattern based on the following features: increased capillaries loop length, increased tortuosity and meandering, well visualized subpapillary plexus, dilatated capillaries without avascular areas [29].

Among the SLE-related antibodies, only the anti-Ro/ SS-A antibodies were related to NFC changes, lower capillaroscopic density respecttively [29], even if it was previously suggested that SLE patients with anti-U1-RNP present more often scleroderma pattern with enlarged loops and avascular areas, while those with microhemorrhages more prevalent APS antibodies [65].

\subsection{Sjogren's syndrome}

Around $30 \%$ of the patients with primary SS develop RP [66]. Regarding the NFC findings in primary SS, one study that included 61 consecutive patients found normal pattern or non-significant capillaries alterations in 59\% of the cases. Moreover, 29.5\% primary SS patients expressed non-specific abnormalities, while $11.5 \%$ a scleroderma-like pattern [66]. Another study that evaluated 136 patients with primary SS, reported normal in $41 \%$, non-specific in $27 \%$, and scleroderma pattern in $10 \%$ cases [67]. Also, the NFC changes were more frequent in patients with SS and RP, 40\% versus 10\% [67].

When comparing primary SS with healthy subjects, non-specific capillaries abnormalities like crossed capillaries to more specific ones like confluent hemorrhages and pericapillary hemorrhages are found [68]. Hemorrhages were found in $31.2 \%$ and pericapillary hemorrhages in $18.7 \%$ patients, while 2 out of 16 patients with primary SS and RP had scleroderma like pattern [68]. All patients with primary SS who were positive for anticentromere antibodies had modified NFC exam and among them, $80 \%$ a scleroderma like pattern [68]. Also, capillaries density was inversely correlated with the RP presence in primary SS [68]. Giant or bushy capillaries are not generally found in SS [69]. There are also reports that do not found NFC changes in primary SS, but only dysregulation of the reactive hyperemia response, an increased time to reach the maximum capillary red blood cell velocity [70]. The attempts to identify differences between the NFC images in SS compared to SLE [71], with cutaneous vasculitis development [72], or to anti-Ro/SS-A, anti-La/SSB failed [67].

\subsection{Psoriatic arthritis}

The vascular injury could play a role in psoriasis pathogenesis [73] which starts with the vascular endothelium activation [74]. About $32.4 \%$ of the patients with psoriatic arthritis (PA) have RP [75]. When compared to controls, the amplitude of the capillaries loop was higher, the 
capillaries density was lower, the number of twisted capillaries and the tortuosity was higher in psoriasis with/ without AP [74]. In almost $60 \%$ of the AP patients tight terminal convolutions of the examined capillaries were found [75].

Analyzing the NFC in 46 patients with psoriasis versus 50 controls, lower capillaries density, increased avascular areas, and increased number of abnormal capillaries were reported [76]. Even if the skin involvement in psoriasis is not associated with NFC changes found more frequent avascular areas in patients with nail involvement [76]. Also, another research including 44 patients with PA and 44 age- and sex- matched control subjects, found diminished capillaries density in patients with nail disease as well as in those with nail and distal interphalangeal joint involvement [73]. Both arterial and venous capillary loops diameter were smaller in patients with distal interphalangeal joints involvements [73]. Other authors reported higher frequency of tortuous capillaries when comparing 34 patients with psoriatic nail disease with 15 healthy controls [77]. In patients treated by Cyclosporine, improvement of the skin thickness, erythema, scaling, and infiltration degree, were followed by amelioration of the NFC images [78]. Compared to RA, the capillaries abnormalities like mega capillaries, hemorrhages, ramifications, avascular areas seem to be similar in PA and RA, but the number of twisted capillaries is higher in AP when compared to RA [74].

\subsection{Rheumatoid arthritis}

$\mathrm{RP}$ is found in $22.3 \%$ to $30.6 \%$ patients with RA [75,79]. Microvascular changes have also been described in RA, but most findings are nonspecific [80]. The NFC contribution to a definite diagnosis in patients with early arthritis is considered [81].

When compared to AP or control subjects, the diameters of capillaries loops are higher in RA. The trend of expansion of the efferent loop is an early manifestation of the microcirculation vascular damage [74]. From a total of 430 RA patients examined for 4 years, $20.9 \%$ showed scleroderma pattern [82]. Other authors reported $14.5 \%$ RA patients with scleroderma pattern [75].

After performing NFC in 210 patients with RA compared to 50 healthy subjects, higher frequency of tortuosity, dilated and bushy capillaries was reported [79]. The NFC alterations identified in RA patients were not correlated with the ACPA positivity or RA disease activity as assessed by DAS28, but only with RP occurrence [79]. In another research involving RA patients, more prominent subpapillary plexus (69\%) and elongated capillaries $(58 \%)$ were the most frequent NFC alterations [75]. Also, dilatated capillaries were more frequent in RA patients with RP, 78.9\% versus $62.8 \%$ [75]. Compared to healthy subjects, the capillaries density has lower values in RA patients. The capillaries density negatively correlated to the C-reactive protein and positively with the HDL-cholesterol and the cardiac index, being so related to the cardiovascular risk [83].

\section{THE CAPILLAROSCOPY REPORT}

In 2019 the Pan-American League of Associations for Rheumatology (PANLAR) reached a consensus for the standards of capillaroscopy report [4].

The PANLAR recommended that the capillaroscopy report should contain: the patient data (including diagnostic suspicion, work type, habits, medications - a summary of conditions that might affect the capillaroscopic image), RP's onset time, and also characterization of visibility, subpapillary venous plexus, architecture, capillaries density, description of giant capillaries, avascular areas, bushy capillaries, microhemorrhages, ectasia and other abnormalities like thrombosed capillaries, tortuous, crossed and bizarre capillaries. And finally, the NFC-based diagnosis should be noted in the final examination report as well as management suggestions and relevant images.

\section{CONCLUSION}

Lately, important advances have been made for the NFC standardization and its use indications gradually expanded. Also, systematic reviews for NFC use in pathologies including SSc, SLE or DM were published.

The capillaroscopic assessment is recommended in patients presenting with RP, allowing differential diagnosis and early recognition of associated underlying pathologies, as well as in all SSc patients for both diagnosis and treatment follow-up at least yearly. There is still need of data regarding the NFC validity as diagnostic and prognostic tool. 
Capilaroscopia periunghială este una dintre metodele paraclinice importante în evaluarea sclerodermiei sistemice, ce s-a impus în timp, fiind o metodă neinvazivă ce permite descrierea patului microvascular .

Calitativ, aspectul capilaroscopic normal este caracterizat printr-o aranjare omogenă, paralelă a anselor capilarelor așezate pe ultimul rând, la fel ca și prin prezența de capilare în ac de păr sau care prezintă variații nespecifice ca formele tortuoase și/ sau încrucișate.

Capilaroscopia periunghială este recomandată pentru evaluarea tuturor pacienţilor care prezintă fenomen Raynaud. Cronologic, apariţia capilarelor gigante este primul indiciu relevant pentru dezvoltarea unei afecţiuni din spectrul patologiilor de tip scleroderma (sclerodermie sistemică, dermatomiozita, boala nediferenţiată şi boala mixtă de ţesut conjunctiv). Colapsul anselor gigante produce microhemoragii şi, mai departe, pierderea de capilare cu ischemie secundară şi neoangiogeneză, ce poate fi observată ca apariţie de capilare ramificate, cu aspect arborescent. Capilaroscopia periunghială este utilă în special în sclerodermia sistemică, fiind de altfel inclusă în criteriile de clasificare ale acestei patologii.

Plecând de la aceste caracteristici importante (capilare gigante, microhemoragii, avascularitate şi neoangiogeneză), trei stagii evolutive au fost descrise în sclerodermia sistemică, şi anume tipar precoce, activ şi tardiv.

In alte boli de tesut conjunctiv decât cele care au caracteristici comune cu sclerodermia sistemică, cum ar fi lupusul eritematos sistemic, artropatia psoriazică sau sindromul antifosfolipidic, interesul pentru capilaroscopie este în creştere, dar încercările de a defini caracteristici specifice în aceste boli au eşuat până acum.

In afara aprecierii calitative, sunt propuse şi metode de evaluare semicantitativă şi cantitativă în capilaroscopie. Recent, sisteme automate sunt în curs de dezvoltare. $C u$ toate acestea, sunt încă necesare studii suplimentare care să susţină utilitatea capilaroscopiei ca test diagnostic şi prognostic.

Correspondence to: Alina Dima, MD, PhD; Department of Rheumatology, Colentina Clinical Hospital, 19-21 Stefan cel Mare Street RO-020125 Bucharest S2, Romania.E-mail: alina_dima@ outlook.com.

Funding: No specific grant from any public agency, commercial or not-for-profit sectors was received for the presented research.

Conflict of interest disclosure: None of the authors has any interests that would constitute a conflict of interest with the current article.

Acknowledgements: Nothing to declare.

Images: All nailfold capillaroscopy images are from dr Magda Ileana Parvu collection.

\section{REFERENCES}

1. KAYSER C., BREDEMEIER M., CALEIRO MT., CAPOBIANCO K., FERNANDES TM., DE ARAUJO FONTENELE SM., et al. Position article and guidelines 2018 recommendations of the Brazilian Society of Rheumatology for the indication, interpretation and performance of nailfold capillaroscopy. Adv Rheumatol. 2019;59(5):1-13.

2. CUTOLO M., SMITH V. Nailfold capillaroscopy. Scleroderma: From Pathogenesis to Comprehensive Management. Springer US; 2012. p. 331-46.

3. CUTOLO M., MELSENS K., HERRICK AL., FOELDVARI I., DESCHEPPER E., DE KEYSER F., et al. Reliability of simple capillaroscopic definitions in describing capillary morphology in rheumatic diseases. Rheumatol (United Kingdom). 2018;57(4):757-9.

4. BERTOLAZZI C., VARGAS GUERRERO A., RODRÍGUEZ-REYNA TS., SANDOVAL H., ÁLVAREZ-HERNÁNDEZ E., AUDISIO MJ., et al. Pan-American League of Associations for Rheumatology (PANLAR) capillaroscopy study group consensus for the format and content of the report in capillaroscopy in rheumatology. Clin Rheumatol. 2019;38(9):2327-37. 
5. CUTOLO M. Atlas of capillaroscopy in rheumatic diseases. Elsevier 2010:25-43.

6. BUCHANAN IS., HUMPSTON DJ. Nail-fold capillaries in connective-tissue disorders. Lancet. 1968;291(7547):845-7.

7. MARICQ HR., CARWILE LEROY E. Patterns of finger capillary abnormalities in connective tissue disease by "wide-field" microscopy. Arthritis Rheum. 1973;16(5):619-28.

8. FAGGIOLI P., TAMBURELLO A., SCIASCERA A., GILARDI AG., MAZZONE A. Nailfold videocapillaroscopy in internal medicine. Ital J Med. 2015;9(3):234-42.

9. MARICQ HR., MAIZE JC. Nailfold capillary abnormalities. Vol. 8, Clinics in Rheumatic Diseases. 1982.p. 455-78.

10. CUTOLO M., SULLI A., PIZZORNI C., ACCARDO S. Nailfold videocapillaroscopy assessment of microvascular damage in systemic sclerosis. J Rheumatol. 2000;27(1):155-60.

11. EMRANI Z., KARBALAIE A., FATEMI A., ETEHADTAVAKOL M., ERLANDSSON BE. Capillary density: An important parameter in nailfold capillaroscopy. Microvasc Res [Internet]. 2017;109:7-18. Available from: http://dx.doi.org/10.1016/j.mvr.2016.09.001

12. CUTOLO M., SMITH V. State of the art on nailfold capillaroscopy: A reliable diagnostic tool and putative biomarker in rheumatology? Rheumatol (United Kingdom). 2013;52(11):1933-40.

13. VAN DEN HOOGEN F., KHANNA D., FRANSEN J., JOHNSON SR., BARON M., TYNDALL A., et al. 2013 Classification Criteria for Systemic Sclerosis: An American College of Rheumatology/European League Against Rheumatism Collaborative Initiative. Arthritis Rheum 2013;65(11):2737-47.

14. PAXTON D., PAULING JD. Does nailfold capillaroscopy help predict future outcomes in systemic sclerosis? A systematic literature review. Semin Arthritis Rheum 2018;48:482-94. doi:10.1016/j.semarthrit.2018.02.005

15. SMITH V., HERRICK AL., INGEGNOLI F., DAMJANOV N., ANGELIS, DENTON CP., et al. Standardisation of nailfold capillaroscopy for the assessment of patients with Raynaud's phenomenon and systemic sclerosis. Autoimmun Rev [Internet]. 2020;(xxxx):102458. Available from: https://doi.org/10.1016/j.autrev.2020.102458

16. CUTOLO M., SUlli A., SMITH V. How to perform and interpret capillaroscopy. Best Pract Res Clin Rheumatol. 2013; 27(2):237-48.

17. ROLDAN LMC., FRANCO CJV., NAVAS MAM. Capillaroscopy in systemic sclerosis: A narrative literature review. Rev Colomb Reumatol. 2016;23(4):250-8.

18. INGEGNOLI F., GUALTIEROTTI R., LUBATTI C., BERTOLAZZI C., GUTIERREZ M., BORACCHI P., et al. Nailfold capillary patterns in healthy subjects: A real issue in capillaroscopy. Microvasc Res. 2013;90:90-5.

19. TAVAKOL ME., FATEMI A., KARBALAIE A., EMRANI Z., ERLANDSSON BE. Nailfold capillaroscopy in rheumatic diseases: which parameters should be evaluated? Biomed Res Int. 2015: 974530.

20. INGEGNOLI F., GUALTIEROTTI R. A systematic overview on the use and relevance of capillaroscopy in systemic sclerosis. Expert Rev Clin Immunol. 2013;9(11):1091-7.

21. CUTOLO M., MELSENS K., TROMBETTA A., PIZZORNI C., DESCHEPPER E., SULLI A., et al. SAT0377 Reliability of a new automated system for absolute capillary number counting (AUTOCAPI) on systemic sclerosis nailfold videocapillaroscopic images. Annals of the Rheumatic Diseases. BMJ; 2017. p. 914.1-914.

22. CUTOLO M., TROMBETTA AC., MELSENS K., PIZZORNI C., SUlli A., RUARO B., et al. Automated assessment of absolute nailfold capillary number on videocapillaroscopic images: Proof of principle and validation in systemic sclerosis. Microcirculation 2018 May;25(4):e12447.

23. SELVA-O'CALLAGHAN A., FONOLLOSA-PLA V., TRALLERO-ARAGUÁS E., MARTÍNEZ-GÓMEZ X., SIMEONAZNAR CP., LABRADOR-HORRILLO M., et al. Nailfold capillary microscopy in adults with inflammatory myopathy. Semin Arthritis Rheum. 2010;39(5):398-404

24. LIN KM., CHENG TT., CHEN CJ. Clinical applications of nailfold capillaroscopy in different rheumatic diseases. J Intern Med Taiwan. 2009;20(3):238-47.

25. SOUBRIER C., SEGUIER J., DI COSTANZO MP., EBBO M., BERNIT E., JEAN E., et al. Nailfold videocapillaroscopy alterations in dermatomyositis, antisynthetase syndrome, overlap myositis, and immune-mediated necrotizing myopathy. Clin Rheumatol. 2019;38(12):3451-8.

26. MIHAI C., SMITH V., DOBROTA R., et al. The emerging application of semi-quantitative and quantitative capillaroscopy in systemic sclerosis. Microvasc. Res. 2018;118:113-20. doi:10.1016/j.mvr.2018.03.00

27. MANFREDI A., SEBASTIANI M., CASSONE G., PIPITONE N., GIUGGIOLI D., COLACI M., et al. Nailfold capillaroscopic changes in dermatomyositis and polymyositis. Clin Rheumatol. 2015;34(2):279-84.

28. KAYSER C., SEKIYAMA JY., PRÓSPERO LC., CAMARGO CZ., ANDRADE LEC. Nailfold capillaroscopy abnormalities as predictors of mortality in patients with systemic sclerosis. Clin Exp Rheumatol. 2013;31(SUPPL.76).

29. CUTOLO M., MELSENS K., WIJNANT S., INGEGNOLI F., THEVISSEN K., DE KEYSER F., et al. Nailfold capillaroscopy in systemic lupus erythematosus: A systematic review and critical appraisal. Autoimmun Rev. 2018;17(4):344-52.

30. CHOJNOWSKI MM., FELIS-GIEMZA A., OLESIŃSKA. Capillaroscopy - A role in modern rheumatology. Reumatologia. 2016;54(2):67-72.

31. INGEGNOLI F., BORACCHI P., GUALTIEROTTI R., LUBATTI C., MEANI L., ZAHALKOVA L., et al. Prognostic model based on nailfold capillaroscopy for identifying Raynaud's phenomenon patients at high risk for the development of a scleroderma spectrum disorder: PRINCE (Prognostic Index for Nailfold Capillaroscopic Examination). Arthritis Rheum. 2008;58(7):2174-82.

32. INGEGNOLI F., BORACCHI P., GUALTIEROTTI R., BIGANZOLI EM., ZENI S., LUBATTI C., et al. Improving outcome prediction of systemic sclerosis from isolated Raynaud's phenomenon: role of autoantibodies and nail-fold capillaroscopy. Rheumatology (Oxford). 2010;49(4):797-805.

33. KOENIG M., JOYAL F., FRITZLER M.J., et al. Autoantibodies and microvascular damage are independent predictive factors for the progression of Raynaud's phenomenon to systemic sclerosis: A twenty-year prospective study of 586 patients, with validation of proposed criteria for early systemic sclerosis. Arthritis Rheum 2008;58:3902-12. doi:10.1002/art.24038 
34. BERTOLAZZI C., CUTOLO M., SMITH V., GUTIERREZ M. State of the art on nailfold capillaroscopy in dermatomyositis and polymyositis. Semin Arthritis Rheum. 2017;47(3):432-44.

35. JEE AS., ADELSTEIN S., BLEASEL J., KEIR GJ., NGUYEN M., SAHHAR J., et al. Clinical Medicine Role of Autoantibodies in the Diagnosis of Connective-Tissue Disease ILD (CTD-ILD) and Interstitial Pneumonia with Autoimmune Features (IPAF). J Clin Med. 2017 May 4;6(5):51.

36. AVOUAC J., FRANSEN J., WALKER UA., RICCIERI V., SMITH V., MULLER C., et al. Preliminary criteria for the very early diagnosis of systemic sclerosis: Results of a Delphi consensus study from EULAR scleroderma trials and research group. Ann Rheum Dis. 2011;70(3):476-81.

37. ØSTENSEN M., ANDREOLI L., BRUCATO A., CETIN I., CHAMBERS C., ClOWSE MEB., et al. State of the art: Reproduction and pregnancy in rheumatic diseases. Autoimmun Rev. 2015;14(5):376-86.

38. SULLI A., SECCHI M.E., PIZZORNI C., CUTOLO M. Scoring the nailfold microvascular changes during the capillaroscopic analysis in systemic sclerosis patients. Ann Rheum Dis. 2008 ;67(6):885-7.

39. SMITH V., VANHAECKE A., HERRICK A.L., et al. Fast track algorithm: How to differentiate a "scleroderma pattern" from a "non-scleroderma pattern". Autoimmun. Rev. 2019;18. doi:10.1016/j.autrev.2019.102394

40. RICCIERI V., VASILE M., IANNACE N., STEFANANTONI K., SCIARRA I., VIZZA CD., et al. Systemic sclerosis patients with and without pulmonary arterial hypertension: A nailfold capillaroscopy study. Rheumatol (United Kingdom). 2013;52(8):1525-8.

41. SCUSSEL-LONZETTI L., JOYAL F., RAYNAULD JP., ROUSSIN A., RICH É., GOULET JR., et al. Predicting mortality in systemic sclerosis: Analysis of a cohort of 309 French Canadian patients with emphasis on features at diagnosis as predictive factors for survival. Medicine (Baltimore). 2002;81(2):154-67.

42. GUILLEN-DEL-CASTILlO A., SIMEON-AZNAR CP., CALLEJAS-MORAGA EL., TOLOSA-VILELLA C., ALONSOVILA S., FONOLLOSA-PLA V., et al. Quantitative videocapillaroscopy correlates with functional respiratory parameters: A clue for vasculopathy as a pathogenic mechanism for lung injury in systemic sclerosis. Arthritis Res Ther. 2018;20(1):1-10.

43. SEBASTIANI M., MANFREDI A., COLACI M., DAMICO R., MALAGOLI V., GIUGGIOLI D., et al. Capillaroscopic skin ulcer risk index: A new prognostic tool for digital skin ulcer development in systemic sclerosis patients. Arthritis Care Res. 2009;61(5):688-94.

44. PIGNATARO F., MAGliONE W., MiNNITI A., SAMBATARO D., SAMBATARO G., CAMPANARO F., et al. NEMO score in nailfold videocapillaroscopy is a good tool to assess both steady state levels and overtime changes of disease activity in patients with systemic sclerosis: A comparison with the proposed composite indices for this disease status entity. Arthritis Res Ther. 2019;21(1):1-8.

45. FRIEDRICH S., LÜDERS S., KLOTSCHE J., et al. The first composite score predicting Digital Ulcers in systemic sclerosis patients using Clinical data, Imaging and Patient history-CIP-DUS. Arthritis Res Ther. 2020;22(1):1-6.

46. DE ANGELIS R., CERIONI A., DEL MEDICO P., BLASETTI P. Raynaud's phenomenon in undifferentiated connective tissue disease (UCTD). Clin Rheumatol. 2005;24(2):145-51.

47. GARCÍA-GONZÁLEZ M., RODRÍGUEZ-LOZANO B., BUSTABAD S., FERRAZ-AMARO I. Undifferentiated connective tissue disease: Predictors of evolution into definite disease. Clin Exp Rheumatol. 2017;35(5):739-45.

48. VALENTINI G., VETTORI S., CUOMO G., IUDICI M., D’ABROSCA V., CAPOCOTTA D., et al. Early systemic sclerosis: short-term disease evolution and factors predicting the development of new manifestations of organ involvement. Arthritis Res Ther. 2012;14(4):R188.

49. DIMA A., JURCUT C., BAICUS C. The impact of anti-U1-RNP positivity: systemic lupus erythematosus versus mixed connective tissue disease. Rheumatology International. 2018.

50. DIÓGENES ADHM., BONFÁ E., FULlER R., CALEIRO MTC. Capillaroscopy is a dynamic process. Lupus. 2007;16(4):254-8.

51. CIANG NCO., PEREIRA N., ISENBERG DA. Mixed connective tissue disease-enigma variations? Rheumatology (Oxford). 2017 Mar 1;56(3):326-333

52. PAOLINO S., FERRARI G., PIZZORNI C., PATANE M., SMITH V., CUTOLO M., et al. Long-term follow-up of nailfold videocapillaroscopic microvascular parameters in mixed connective tissue disease versus systemic sclerosis patients: a retrospective cohort study. Clin Exp Rheumatol. 2019;37 Suppl 119(4):102-107.

53. MARICQ HR., LEROY EC., D'ANGELO WA., MEDSGER TA., RODNAN GP., SHARP GC., et al. Diagnostic potential of in vivo capillary microscopy in scleroderma and related disorders. Arthritis Rheum. 1980; 23(2):183-9.

54. GRANIER F., VAYSSAIRAT M., PRIOLLET P., HOUSSET E. Nailfold capillary microscopy in mixed connective tissue disease. Comparison with systemic sclerosis and systemic lupus erythematosus. Arthritis Rheum. 1986;29(2):189-95.

55. CIANG NCO., PEREIRA N., ISENBERG DA. Mixed connective tissue disease-enigma variations? Rheumatology (Oxford). 2017 Mar 1;56(3):326-333.

56. CELINSKA-LÖWENHOFF M., PASTUSZCZAK M., PELKA K., STEC-POLAK M., WOJAS-PELC A., MUSIAL J. Associations between nailfold capillaroscopy findings and interstitial lung disease in patients with mixed connective tissue disease. Arch Med Sci. 2020;16(2):297-301.

57. ASCHWANDEN M., DAIKELER T., JAEGER KA., THALHAMMER C., GRATWOHL A., MATUCCI-CERINIC M., et al. Rapid improvement of nailfold capillaroscopy after intense immunosuppression for systemic sclerosis and mixed connective tissue disease. Ann Rheum Dis. 2008 Jul;67(7):1057-9.

58. OLDROYD A., LILLEKER J., CHINOY H. Idiopathic inflammatory myopathies-a guide to subtypes, diagnostic approach and treatment. Clin Med J R Coll. Physicians London. 2017;17:322-8. doi:10.7861/clinmedicine.17-4-322

59. VAZ JLP., DANCOUR MAA., BOTTINO DA., BOUSKELA E. Nailfold videocapillaroscopy in primary antiphospholipid syndrome (PAPS). Rheumatology. 2004;43(8):1025-7. 
60. CANDELA M., PANSONI A., DE CAROLIS ST., POMPONIO G., CORVETTA A., GABRIELLI A., et al. Nailfold capillary microscopy in patients with antiphospholipid syndrome. Recenti Prog Med. 1998;89(9).

61. RAEESKARAMI SR., NAMAZI N., ASSARI R., NAJAFIZADEH SR., HASSANNEJAD Z., ZIAEE V. The Comparison of Nailfold Capillaroscopy between Juvenile Systemic Lupus Erythematosus and Healthy Controls: Correlation with Laboratory and Clinical Parameters. Int J Vasc Med. 2020;2020.

62. LIN KM., CHENG TT., CHEN CJ. Clinical Applications of Nailfold Capillaroscopy in Different Rheumatic Diseases. Gung Memorial Hospital C. 2009;20:238-247.

63. ASLANIDIS S., PYRPASOPOULOU A., DOUMAS M., TRIANTAFYLLOU A., CHATZIMICHAILIDOU S., ZAMBOULIS C. Association of capillaroscopic microhaemorrhages with clinical and immunological antiphospholipid syndrome. Clin Exp Rheumatol. 2011;29(2):307-9.

64. PYRPASOPOULOU A., TRIANTAFYLLOU A., ANYFANTI P., DOUMA S., ASLANIDIS S. Capillaroscopy as a screening test for clinical antiphospholipid syndrome. Eur J Intern Med. 2011;22(6):e158-9.

65. FAGGIOLI P., TAMBURELLO A., SCIASCERA A., GILARDI AG., MAZZONE A. Nailfold videocapillaroscopy in internal medicine. Italian Journal of Medicine. Vol. 9. Page Press Publications; 2015;9:234-42.

66. CAPOBIANCO KG., XAVIER RM., BREDEMEIER M., RESTELLI VG., BRENOL JCT. Nailfold capillaroscopic findings in primary Sjögren's syndrome: Clinical and serological correlations. Clin Exp Rheumatol. 2005;23(6):789-94.

67. COROMINAS H., ORTIZ-SANTAMARIA V., CASTELLVI I., MORENO M., MORLA R., CLAVAGUERA T., et al. Nailfold capillaroscopic findings in primary Sjögren's syndrome with and without Raynaud's phenomenon and/or positive antiSSA/Ro and anti-SSB/La antibodies. Rheumatol Int. 2016;36(3):365-9.

68. TEKTONIDOU M., KASKANI E., SKOPOULI FN., MOUTSOPOULOS HM. Microvascular abnormalities in Sjogren's syndrome: Nailfold capillaroscopy. Rheumatology. 1999;38(9):826-30.

69. SZABO N., CSIKI Z., SZANTO A., DANKO K., SZODORAY P., ZEHER M. Functional and morphological evaluation of hand microcirculation with nailfold capillaroscopy and laser Doppler imaging in Raynaud's and Sjögren's syndrome and poly/dermatomyositis. Scand J Rheumatol. 2008;37(1):23-9.

70. AGUIAR T., FURTADO E., DORIGO D., BOTTINO D., BOUSKELA E. Nailfold videocapillaroscopy in primary sjögren's syndrome. Angiology. 2006;57(5):593-9.

71. OHTSUKA T. Nailfold capillary abnormalities in patients with Sjogren's syndrome and systemic lupus erythematosus. Br J Dermatol. 1997;136(1):94-6.

72. SCOFIELD RH. Vasculitis in Sjögren's Syndrome. Curr Rheumatol Rep. 2011 Dec; 13(6): 482-488.

73. BHUSHAN M., MOORE T., HERRICK AL., GRIFFITHS CEM. Nailfold video capillaroscopy in psoriasis. Br J Dermatol. 2000;142(6):1171-6.

74. GRACEFFA D., AMOROSI B., MAIANI E., BONIFATI C., CHIMENTI MS., PERRICONE R., et al. Capillaroscopy in psoriatic and rheumatoid arthritis: A useful tool for differential diagnosis. Arthritis. 2013;2013:957480.

75. LAMBOVA SN., MÜLLER-LADNER U. Capillaroscopic pattern in inflammatory arthritis. Microvasc Res. 2012;83(3):318-22.

76. RIBEIRO CF., SIQUEIRA EBD., HOLLER AP., FABRÍCIO L., SKARE TL. Capilaroscopia periungueal em psoríase. An Bras Dermatol. 2012;87(4):550-3.

77. UREYEN SB., KARA RO., ERTURK Z., YALDIZ M. The microvascular and morphostructural changes of nails in psoriatic patients with nail disease; A link between ultrasound and videocapillaroscopy findings in the nailfold. Med Ultrason. 2018;20(2):185-91.

78. MUSUMECI ML., LACARRUBBA F., FUSTO CM., MICALI G. Combined clinical, capillaroscopic and ultrasound evaluation during treatment of plaque psoriasis with oral cyclosporine. Int J Immunopathol Pharmacol. 2013;26(4):1027-33.

79. SAG S., SAG MS., TEKEOGLU I., KAMANLI A., NAS K., AYDIN Y. Nailfold videocapillaroscopy results in patients with rheumatoid arthritis. Clin Rheumatol. 2017;36(9):1969-74.

80. MCGILL NW., GOW PJ. Nailfold Capillaroscopy: a Blinded Study of Its Discriminatory Value in Scleroderma, Systemic Lupus Erythematosus, and Rheumatoid Arthritis. Aust N Z J Med. 1986;16(4):457-60.

81. FlOREA M., ROŞU A., VREJU FA., MUŞETESCU AE., CRIVEANU C., CIUREA P. Contribution of Nail Fold Videocapillaroscopy in Patients with Early Inflammatory Arthritis. Curr Heal Sci J. 2015;41(3):233-8.

82. RAJAEI A., DEHGHAN P., AMIRI A. Nailfold capillaroscopy in 430 patients with rheumatoid arthritis. Casp J Intern Med. 2017;8(4):269-75.

83. ANYFANTI P., GKALIAGKOUSI E., TRIANTAFYLLOU A., ZABULIS X., DOLGYRAS P., GALANOPOULOU V., et al. Dermal capillary rarefaction as a marker of microvascular damage in patients with rheumatoid arthritis: Association with inflammation and disorders of the macrocirculation. Microcirculation. 2018;25(5):0-2.

Received $3^{\text {rd }}$ December 2020 